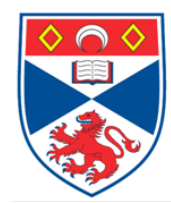

Full metadata for this item is available in Research@StAndrews:FullText at: http://research-repository.st-andrews.ac.uk/

'Re-inscribing De Quincey's Palimpsest: The Significance of the Palimpsest in Contemporary Literary and Cultural Studies'

Sarah Dillon

\begin{tabular}{|l|l|}
\hline Date of deposit & $7 / 11 / 12$ \\
\hline Version & $\begin{array}{l}\text { This is an author post-peer review but pre-copy } \\
\text { edited version of this work. }\end{array}$ \\
\hline Access rights & $\begin{array}{l}\text { C This item is protected by original copyright. } \\
\text { This work is made available online in accordance } \\
\text { with publisher policies. To see the final definitive } \\
\text { version of this paper please visit the publisher's } \\
\text { website. }\end{array}$ \\
\hline $\begin{array}{l}\text { Citation } \\
\text { published } \\
\text { version }\end{array}$ & $\begin{array}{l}\text { Dillon, Sarah, 'Re-inscribing De Quincey's Palimpsest: } \\
\text { The Significance of the Palimpsest in Contemporary } \\
\text { Literary and Cultural Studies', Textual Practice 19:3 } \\
\text { (2005), 243-263. }\end{array}$ \\
\hline $\begin{array}{l}\text { Link } \\
\text { published } \\
\text { version }\end{array}$ & to
\end{tabular}




\section{Reinscribing De Quincey's Palimpsest: The Significance of The Palimpsest in Contemporary Literary and Cultural Studies}

\section{Sarah Dillon}

In 1845, Thomas De Quincey published an essay entitled 'The Palimpsest'. Coupling 'palimpsest' with the definite article 'the' (for the first time in a non-specific sense) De Quincey's essay inaugurated - that is, both introduced, and initiated the subsequent use of - the substantive concept of the palimpsest. The palimpsest is implicitly related to palimpsests, which until 1845 were palaeographic oddities of concern only to those researching and publishing ancient manuscripts. However, the concept of the palimpsest also exists independently of such phenomena - it is a strange, new figurative entity, invested with the stature of the substantive. De Quincey was not the first writer to use palimpsests in a figurative sense. ${ }^{1}$ However, his inauguration of the concept of the palimpsest marks the beginning of a consistent process of metaphorisation of palimpsests from the mid-nineteenth century (the most prolific period of palimpsest discoveries) to the present day.

Since 1845 , the concept of the palimpsest has been employed in areas as diverse as architecture, geography, geology, palaeontology, glaciology, astrophysics, biochemistry, genetics, neuroscience, neurobiology, neurocomputing, and information technology. It also occurs frequently in creative, critical and theoretical texts across the expansive fields of literature, philosophy and cultural studies. This essay brings together some of those diverse texts - beginning with De Quincey's - in order to draw attention to how the palimpsest is reinscribed in and by a broad range of contemporary critical 
discourses, including deconstruction, psychoanalysis, postcolonial theory, feminism and queer theory. Moreover, the structure and logic of the palimpsest is crucial to these discourses' rethinking of such key contemporary issues as the subject, time, history, culture, gender and sexuality, and the processes of reading and writing themselves. As I explore in the conclusion with my coupling of queer and the palimpsest, the movement of elucidation here is reciprocal and simultaneous: the palimpsest reifies and aids the understanding of current ideas and concepts; at the same time, those ideas and concepts enable a reinscription of the palimpsest that sophisticates our understanding of its complex structure and logic.

\section{Introducing 'Palimpsestuousness'}

Before discussing the significance of the concept of the palimpsest in current critical discourse, I would like to introduce the neologistic adjective from the palimpsest: 'palimpsestuous'. This is an adjective that has gained critical currency in recent years, and that I will employ throughout this essay as a shorthand for the logic and structure of the palimpsest that is so crucial to contemporary literary and cultural discourse.

In the Oxford English Dictionary, a palimpsest is defined as,

a parchment or other writing-material written upon twice, the original writing having been erased or rubbed out to make place for the second; a manuscript in which a later writing is written over an effaced earlier writing. 
Palimpsests were created from the seventh to fifteenth centuries primarily in the scriptoriums of the great monastic institutions such as Bobbio, Luxeuil, Fleury, Corbie and St. Gall. Such recycling of vellum arose due to a combination of factors: scarcity and expense of writing material; physical deterioration of existing manuscripts from which reusable vellum was then sourced; and, changing historical and cultural factors which rendered some texts obsolete either because the language in which they were written could no longer be read, or because their content was no longer valued. Palimpsests were created by a process of layering whereby the existing text was erased, using various chemical methods, and the new text was written over the old one. But the most peculiar and interesting fact about palimpsests is omitted from the OED definition. Palimpsests are of such interest to subsequent generations because although the first writing on the vellum seemed to have been eradicated after treatment, it was often imperfectly erased. Its ghostly trace then reappeared in the following centuries as the iron in the remaining ink reacted with the oxygen in the air producing a reddish brown oxide. This process has been encouraged by the use of chemical reagents and ultraviolet light in the nineteenth and early twentieth centuries, and by more advanced imaging technologies in the late twentieth and early twenty-first centuries.

Although the process that creates palimpsests is one of layering, the result of that process is a surface structure which can be described by a term coined by Thomas De Quincey - 'involuted'. 'Involute' is De Quincey's name for the way in which

our deepest thoughts and feelings pass to us through perplexed combinations of concrete objects...in compound experiences incapable of being disentangled. ${ }^{2}$ 
The adjective 'involuted' describes the relationship between the texts that inhabit the palimpsest as a result of the process of palimpsesting and subsequent textual reappearance. The palimpsest is an involuted phenomenon where otherwise unrelated texts are involved and entangled, intricately interwoven, interrupting and inhabiting each other. Another word that describes this structure is the neologism 'palimpsestuous'.

The OED definition states that the adjective from 'palimpsest' is 'palimpsestic', meaning, 'that is, or that makes, a palimpsest'. Recently, this official adjective has been rejected in favour of 'palimpsestuous'. 'Palimpsestuous' does not name something as, or as making, a palimpsest. Rather, it is describes the complex (textual) relationality embodied in the palimpsest. Where 'palimpsestic' refers to the process of layering that produces a palimpsest, 'palimpsestuous' describes the structure that one is presented with as a result of that process, and the subsequent reappearance of the underlying script. De Quincey's concept of the palimpsest made strange and revitalised palaeographic palimpsests. In the same way, 'palimpsestuous' makes that concept strange, and helps to rewrite and refigure the palimpsest in the context of late twentieth and early twenty-first century literary and cultural thought.

\section{Deconstruction: Thomas De Quincey and the Palimpsest of the Mind}

I will begin my exploration of the palimpsest by offering a reading of De Quincey's inaugural use of this figure in constructing the notion of the palimpsest of the mind - a resurrective fantasy with which De Quincey attempts to secure the continued life of his sister Elizabeth. In contrast to previous commentators, I argue that the 
thought of Jacques Derrida offers a way of understanding the post-romantic spectralisation of the self that arises from this fantasy, as well as the uncanny type of 'living on' that De Quincey secures for Elizabeth with it.

In his opening discussion of palaeographic palimpsests in 'The Palimpsest', De Quincey's imagination is captured by the strange successful failure of the initial erasure, and the subsequent reappearance of the underlying script. As a result, De Quincey creates the fantasy of 'the palimpsest of the human brain':

What else than a natural and mighty palimpsest is the human brain? Such a palimpsest is my brain; such a palimpsest, O reader! is yours. Everlasting layers of ideas, images and feelings, have fallen upon your brain softly as light. Each succession has seemed to bury all that went before. And yet in reality not one has been extinguished. (TDQ, 144)

In Suspiria de Profundis (1845) (the fragmentary sequel to the Confessions of an English Opium Eater (1821), in which 'The Palimpsest' is collected), the figure of the palimpsest of the mind reassures De Quincey that all the impressions made on it 'are not dead but sleeping' (TDQ, 146). It confirms his belief - voiced twenty-four years earlier in the passage in the Confessions that prefigures 'The Palimpsest' - 'that there is no such thing as forgetting possible to the mind' (TDQ, 69). As such, it offers the reassurance that erasure and death, even if they appear permanent, can always be reversed - that nothing can properly and truly 'die'. In the Suspiria, the construction of the mind as palimpsest functions specifically as one of a number of resurrective fantasies with which De Quincey attempts to secure the continued life of his sister Elizabeth. (Other such fantasies are the figure of the Spectre of the Brocken and the drowned city of Savannah-La-Mar.) 
Of all the 'mysterious handwritings of grief or joy which have inscribed themselves successively upon the palimpsest of...[his] brain' (TDQ, 146), the 'intolerable grief' of the loss of his sister Elizabeth haunts De Quincey most profoundly:

the deep deep tragedies of infancy, as when the child's hands were unlinked forever from his mother's neck, or his lips for ever from his sister's kisses, these remain lurking below all, and these lurk to the last. Alchemy there is none of passion or disease that can scorch away these immortal impresses. (TDQ, 146)

The resurrective fantasy of the palimpsest of mind provides the assurance that Elizabeth is not dead, but sleeping. That in De Quincey's mind, and through his writing, the 'pall' (not merely a dark covering but, literally, the cloth spread over a coffin or tomb) covering Elizabeth can be drawn off and revive the 'sleeping' Elizabeth beneath. In constantly making Elizabeth visible, De Quincey's fantasies of resurrection are indeed both resurrective, and fantasies - the word fantasy, coming as it does, from the Greek phantasia, literally 'a making visible'. De Quincey's writing repeatedly performs this resurrection of Elizabeth; it continually enacts the impossibility of his forgetting of her.

In 'The Dark Interpreter and the Palimpsest of Violence: De Quincey and the Unconscious' (1981), Robert M. Maniquis reads the palimpsest of the mind, and the other figures of the Suspiria, as De Quincey's fictional autonomous psyches and explores the cycles of violence in which they are implicated. Maniquis is seeking to work through the complex connections between De Quincey's multiple images of the psyche and Christian ideas of salvation and the Word, as well as psychoanalytic and linguistic concepts of the signifier and the signified. Maniquis argues that for De Quincey the palimpsest is a figure of the undying Romantic mind where no impression is ever erased. But he also draws attention to the palimpsest's embodiment of the 
paradox of Christian salvation - the creative violences involved in the process of palimpsesting resemble the creative violence of Christ's sacrifice. Maniquis concludes his discussion of De Quincey's palimpsest of the mind by briefly tracing its transmission into French literature. The figure has entered the writing of Gide, Proust and Genette, amongst others, via Baudelaire's translation of De Quincey in Les paradis artificiels (1860). Maniquis halts the palimpsest's journey suddenly and absolutely in the work of Jacques Derrida. Arguing that all a Derridean text can ever do is 'reveal only its own constantly rupturing order', ${ }^{4}$ he cites a passage from Derrida's double text 'Living On: Border Lines' (1979) as evidence of Derrida's rejection of the concept of the palimpsest:

An apocalyptic superimprinting of texts: there is no paradigmatic text. Only relationships of cryptic haunting from mark to mark. No palimpsest (definitive unfinishedness). No piece, no metonymy, no integral corpus. And thus no fetishism. ${ }^{5}$

Maniquis argues that the palimpsest, as a figure of christological violence and resurrection, as well as of Romantic subjective totality, has no place in the writing of a 'postmodern writer'. ${ }^{6}$ For such a writer has rejected the idea of Platonic sources and considers himself to be only a shadow in a network of shadows, subordinate to the productive violence not of Christianity but of textuality. But attention to the French text of 'Border Lines' reveals that the phrase 'no palimpsest' translates 'pas de palimpseste...', which literally means both 'no palimpsest', and 'a palimpsestuous step'. ${ }^{7}$ In contrast to Maniquis, I would argue that there is in fact a curious - perhaps, palimpsestuous - intimacy between the structure and logic of the palimpsest and Derrida's ideas and formulations, particularly with regard to the subject and temporality. 
For instance, in De Quincey's autobiographical writing, the fantasy of the palimpsest of the mind does not secure a Romantic unity of mind but is instead implicated in a distinctly post-Romantic spectralisation of the self, and of temporality, that is intimately related to Derrida's theorisation of spectrality in Specters of Marx: The State of the Debt, the Work of Mourning, and the New International (1994). In order to secure the fantasy of the palimpsest of the mind from the incoherence of the irrelatedness of the texts in vellum palimpsests, De Quincey posits the existence of 'organizing principles which fuse into harmony, and gather about fixed predetermined centres, whatever heterogeneous elements life may have accumulated from without' (TDQ, 144). In the face of the irrelatedness and incongruity of the experiences, thoughts and feelings recorded in the layers of the brain, these principles do not merely defend against the convulsions that resurrect those layers. Rather, they define, create, and constitute the harmonious and coherent 'grandeur of human unity' (TDQ, 144) that is in need of such defence. These organizing principles are the interpretative powers of the inviolable ' $\mathrm{I}$ ' of the human subject - their task is both to create and protect it. This ' $\mathrm{I}$ ' is the narratorial subject position of any autobiographical writing, including De Quincey's own. But from the very outset of the Suspiria, De Quincey acknowledges a disunity haunting the 'I' upon which autobiography, and the 'grandeur of human unity' (TDQ, 144), depends. In fact, in the 'Introductory Notice', De Quincey recognises that autobiography is only possible precisely because of constitutive difference within the 'I': 'an adult sympathizes with himself in childhood because he $i s$ the same, and because (being the same) yet he is not the same' (TDQ, 92).

De Quincey's doubled 'I' is not simply another manifestation of, in Gerald Gillespie's words, 'the Romantic fascination for the productive interplay between "self" and "otherness". ${ }^{8}$ Rather, in the Suspiria, these two selves rapidly multiply until the 
unity of the self upon which De Quincey insists is ruptured by a distinctly postromantic realisation of the temporal contingency of human identity:

Man is doubtless one by some subtle nexus that we cannot perceive, extending from the newborn infant to the superannuated dotard: but as regards many affections and passions incident to his nature at different stages, he is not one; the unity of man in this respect is coextensive only with the particular stage to which the passions belong. (TDQ, 107)

The fantasy of the palimpsest of the mind, and the disunity of the self it implies, leads inexorably not just to a Romantic notion of the mirrored or doubled self, but to a postromantic notion of the spectralised subject. It represents the mind as a textual structure actively haunted by its encrypted traces. Despite the coherence that De Quincey's interpretative ' $\mathrm{I}$ ' is supposed to secure, the fantasy of the palimpsest of the human brain leads to a radical disjunction within the notion of identity, the self and the present, a disjunction theorised in Derrida's Specters of Marx. For Derrida, the (spectral) subject can only be the effect of iterability, of a repetition that is never quite the same. Thus the ' $\mathrm{I}$ ' from which De Quincey is writing is at each moment a different 'I', spectrally constituted by all the 'I's that have preceded it and all the 'I's which it will become. This spectral structure of the self is also inevitably involved with a spectralisation of temporality. The palimpsest visibly represents what Derrida describes as the 'noncontemporaneity with itself of the living present'. ${ }^{9}$ The 'present' of the palimpsest is only constituted in and by the 'presence' of texts from the 'past', as well as remaining open to further inscription by texts of the 'future'. The presence of texts from the past, present (and possibly the future) in the palimpsest does not elide temporality, but evidences the spectrality of any 'present' moment which always already contains within it 'past', 'present' and 'future' moments. 
Furthermore, the idea of 'living on' which Derrida plays out in the companion text to 'Border Lines' shares its uncanny nature with the 'living on' that De Quincey's fantasies of resurrection, including the palimpsest, hope to secure for Elizabeth. If De Quincey can not forget Elizabeth, if his writing can continually revive her, then Elizabeth can never really die. But the continued existence secured for her is not the Christian salvation of eternal life, about which De Quincey remains ambivalent. Rather, repeatedly resurrected and returning in his writing, preserved in the palimpsest of De Quincey's mind, Elizabeth exists in the uncanny state of 'living on' described by Derrida as,

a reprieve or an afterlife, "life after life" or life after death, more life or more than life, and better; the state of suspension in which [life is] over - and over again, and you'll never have done with that suspension itself. ${ }^{10}$

As I will elaborate in the following section, the structure of the palimpsest also embodies precisely the relationship of cryptic haunting to which Derrida alludes in the passage cited above from 'Border Lines'. In fact, Nicolas Abraham and Maria Torok's psychoanalytic theory of the crypt enables a refiguration of the figure of the palimpsest of the mind as a complex structure of cryptic incorporation. As such, I argue it has more in common with their redefinition of the psychoanalytic topography of the self, than it does with that of Freudian psychoanalysis, especially as represented in the model of the Mystic Writing-Pad with which the palimpsest has so often been erroneously associated.

Psychoanalysis: The Cryptic Palimpsest vs. The Mystic Writing-Pad 
In 'Introjection - Incorporation Mourning or Melancholia' (1980), Nicolas Abraham and Maria Torok define fantasy as 'any representation, belief, or body state working...toward the maintenance of the topographical status quo' ${ }^{11}$ Fantasy thus has 'a conservative, preservative function, no matter how innovative in spirit it may be, how broad its field of action, or how great its hidden compliance with wishes' (I, 3-4). The task of understanding a fantasy is specific: one must 'pinpoint, concretely, what topographical change the fantasy is called on to resist' (I, 4). The fantasy under discussion in 'Introjection - Incorporation' is the fantasy of 'incorporation', a fantasy that resists the psychical topographical changes that are the necessary consequence of 'normal' mourning. The fantasy of incorporation magically bypasses this 'normal' process of mourning, named 'introjection'. It does so by both performing and not performing it, 'by carrying out in a literal sense something that has meaning only in a figurative sense' (I, 5). In 'Introjection - Incorporation', Abraham and Torok explain that in the fantasy of incorporation 'a thing or an object' is introduced in whole or in part into the body, as a result of both the refusal to mourn a loss, and the refusal to acknowledge 'the very fact of having had anything to lose' (I, 7). All the words, scenes, tears and trauma of this loss, all the unexpressed grief, builds in the subject 'a secret vault' (I, 8):

In this crypt reposes - alive, reconstituted from the memories of words, images, feelings - the objective counterpart of the loss, as a complete person with his own topography, as well as the traumatic incidents - real or imagined - that had made introjection impossible. (I, 8)

De Quincey's fantasies of resurrection, including the palimpsest of the mind, are part of his refusal to mourn his sister Elizabeth's death 'normally'. As a result, they create and 
consolidate a crypt in his mind that shelters Elizabeth, and the trauma of her death. The palimpsest of the mind can therefore be understood as a structure of cryptic haunting in which Elizabeth 'lives on'. Like the crypt - as Derrida describes it in 'Fors: the Anglish Words of Nicolas Abraham and Maria Torok', the foreword to their The Wolf Man's Magic Word: A Cryptonymy (1986) - it is 'a topographical arrangement made to keep (conserve-hidden) the living dead'. ${ }^{12}$

The Wolf Man's Magic Word is Abraham and Torok's remarkable analysis of the subject of Freud's famous case From the History of an Infantile Neurosis (1918 [1914]) in which they employ and consolidate their theory of the crypt. One of the key insights of their text is that the notion of cryptic incorporation changes the traditional psychoanalytic topography of the self, for 'the crypt works in the heart of the Ego as a special kind of Unconscious' ${ }^{13}$ In Derrida's elaboration, the crypt is 'a place comprehended within another but rigorously separated from it' (F, xiv), 'a parasitic inclusion, an inside heterogeneous to the inside of the Self' (F, xvi). This idea of cryptic incorporation provides a way of understanding the structure of the palimpsest (of the mind) that is not dictated by the psychical topography of Freudian psychoanalysis. For the palimpsest (of the mind), like the crypt, 'no longer rallies the easy metaphors of the Unconscious (hidden, secret, underground, latent, other, etc.) of the prime object, in sum, of any psychoanalysis' (F, xiii). The so-called 'depth' of the palimpsest which invites such metaphors is in fact illusory. ${ }^{14}$ Rather, the impressions made on the palimpsest (of the mind) live on as cryptic incorporations on its surface. The so-called 'underlying' layer of the palimpsest is in fact, like the crypt, 'a kind of "false unconscious," an "artificial" unconscious lodged like a prosthesis, a graft in the heart of an organ, within the divided self' (F, xiii). 
The palimpsest does not conform structurally to a psychoanalysis of surface and depth, latent and manifest. The palimpsest of the mind is not structurally akin to Freud's first stratified topography of the unconscious, preconscious and conscious systems. Rather, the palimpsest presents a complex structure of cryptic incorporation. The spectralisation of the self that results from this structure indicates that the palimpsest of the mind has more in common figuratively with Freud's second topography, in which the mind is haunted by the ghostly figures of the Id, the Ego and the Superego. It is important to note at this point then, in contrast to previous critical commentary, the marked difference between Freud's model of the Mystic Writing-Pad and De Quincey's fantasy of the palimpsest of the mind.

In 'Writings on the Mind: The Importance of the Palimpsest in Nineteenth Century Thought' (1987), Josephine McDonagh situates the palimpsest within 'a wider tradition of psychological models of the mind', specifically those of 'the Empiricist's tabula rasa and Freud's Mystic Writing-Pad'. ${ }^{15}$ She notes that the difference between the tabula rasa on the one hand, and the Mystic Pad and the palimpsest on the other, is that the former lacks the capacity for the retention of the impressions it receives, whereas the latter retain those impressions. However, the only difference she identifies between the Mystic Pad and the palimpsest is that suggested by the limit Freud places on his analogy - the Mystic Pad cannot bring about the recollection of the memory traces, whereas the palimpsest can. Throughout 'Writings on the Mind', McDonagh discusses the model of the palimpsest, without reflecting upon either the idea of the model, or the strange substantivisation of the palaeographic palimpsest that occurs in the title of De Quincey's essay. Like other commentators, McDonagh fails to recognise the significant difference in De Quincey's essay between palimpsests and the palimpsest. Both the Mystic Pad and palimpsests may satisfy Freud and De Quincey's 
shared belief in the non-possibility of forgetting, in the permanence of the memory traces laid down in the mind. McDonagh may therefore indeed be surprised at Freud's excitement about the novelty of the Mystic Pad, since 'in its capacity to retain inscriptions while always providing a clean surface, $a$ palimpsest already answers both Freud's requirements [my emphasis]'. ${ }^{16}$ It may also be surprising that Freud does not at any point refer to palimpsests in his discussions of the mind, especially as he was undoubtedly aware of their existence. ${ }^{17}$ It may even be that such an omission is an absence symptomatic of Freud's comprehensive elision of De Quincey from his writing. ${ }^{18}$ But this similarity between the model of the Mystic Pad and the potential model of the mind offered by palimpsests does not imply a necessarily corresponding similarity between the Mystic Pad and the fantasy of the palimpsest of the mind as it occurs in De Quincey's essay.

For De Quincey, the single most important fact about palimpsests and the palimpsest is that which Freud can do without in the model of the Mystic Pad - the possibility of recollection. The prime interest of palimpsests and the palimpsest for De Quincey is their implication in resurrection; their retentive function is merely a necessary means to that end. Moreover, the palimpsest is a fantasy in De Quincey's writing, not a model. The Mystic Pad is the result of Freud's life-long search for a technical model that will seriously represent his hypothesis of the psychical structure of the mind. 'A Note upon the Mystic Writing-Pad' (1925 [1924]) is an essay collected amongst others on the metapsychological theories of psychoanalysis. In contrast, De Quincey's figure of the palimpsest of the mind occurs in an autobiographical text as a personal fantasy of resurrection. It is not a model of the mind but a delusive imagining, a hallucination, a daydream arising from De Quincey's unconscious wishes and attitudes, an extravagant and visionary fancy, a product of the imagination, a fiction, a 
figment, an ingenious invention. ${ }^{19}$ As such, the palimpsest is not an external model subject to the very limitation of modelling itself - that it will always remain an external representation, 'a mechanism without its own energy', a machine which is dead. ${ }^{20}$ Rather, as a psychological fantasy, it shares in the undecidable status of all fantasies. It is somehow real and not real, both internal and external to the mind. It has a psychical reality that, however, does not preclude its material reality. As with all psychological fantasies, it blurs the very boundaries between internal and external, life and death, presence and representation by which Freud's model of the Mystic Writing-Pad remains bound.

\section{Postcolonial Theory: The Palimpsest, Genealogy, History}

Reading De Quincey intertwined with modern theories of deconstruction and psychoanalysis allows a critical reinscription of the palimpsest, both in De Quincey's writing, and more generally. At the same time, it highlights the way in which the structure and logic of the palimpsest inhabits the thought of these two contemporary critical discourses. In the last three sections of this essay, I would like to move away from De Quincey in order to explore the palimpsest's significance in other areas of current critical inquiry, namely, postcolonial theory, feminism, and queer theory. Firstly, in this section, I will show how the concept of the palimpsest haunts Michael Foucault's view of history, and the kind of historical postcolonial reading and writing that history requires.

In 'Nietzsche, Genealogy, History' (1971), Foucault elaborates, after Nietzsche, the concept of 'genealogy'. In doing so, he reinscribes the traditional understanding of 
the process of writing history. Integral to this reinscription is the refiguration of the subject of that writing - 'history' - as a collection of palimpsestuous documents:

Genealogy is gray, meticulous, and patiently documentary. It operates on a field of entangled and confused parchments, on documents that have been scratched over and recopied many times. ${ }^{21}$

In response to the palimpsestuous body of history, Foucault's work outlines a new kind of historical reading and writing that combines the archaeological with the genealogical. These dual aspects of reading and writing correspond exactly to the dual responses to the palimpsest, what I term palimpsest reading, and palimpsestuous reading.

Traditional palimpsest reading has as its sole aim and objective the resurrection of the underlying script; the overlying one is irrelevant. In 'Palimpsest Literature, And Its Editor, Cardinal Angelo Mai' (1867), Charles William Russell notes this singlemindedness of the palimpsest editor: 'in a palimpsest MS. the chief, and perhaps the sole object of interest is the first or the more or less completely obliterated writing, ${ }^{22}$ Similarly, in Power/Knowledge: Selected Interviews and Other Writings 1972-77 (1980), Foucault explains that the task of the historian is 'the making visible of what was previously unseen' either by magnifying the detail of analysis, or by 'addressing oneself to a layer of material which had hitherto had no pertinence for history and which had not been recognised as having any moral, aesthetic, political or historical value'. ${ }^{23}$ For Foucault, archaeology involves bringing to light

a whole set of knowledges that have been disqualified as inadequate to their task or insufficiently elaborate: naïve knowledges, located low down on the hierarchy, beneath the required level of cognition or scientificity. (PK, 82) 
But, unlike palimpsest editors, Foucault recognises that archaeology must be combined with genealogy, with 'the tactics whereby, on the basis of the descriptions of these local discursivities, the subjected knowledges which were thus released would be brought into play' (PK, 85).

Genealogy traces the 'strategic connections' (PK, 38) between the discourses that have been brought to light. The task of genealogy is not to discover the roots of our identity but to commit itself to its dissipation...to make visible all of those discontinuities that cross us' $(\mathrm{NGH}, 162)$. Genealogy is thus a form of palimpsestuous reading that does not focus solely on the underlying text for to do so would be to unravel and destroy the palimpsest, which exists only and precisely as the involution of texts. Rather, such reading seeks to trace the incestuous and encrypted texts that constitute the palimpsest's fabric. Since those texts bear no necessary relation to each other, palimpsestuous reading is an inventive process of creating relations where there may, or should be, none, hence the appropriateness of its epithet's phonetic similarity to the incestuous.

As the analysis of Herkunft, or descent, genealogy traces the intersection of marks that constitute the unravelable palimpsest that is individual and cultural identity. As an analysis of Entstehung, or emergence (current episodes, not culminations, in the historical series of subjections) genealogy works on the palimpsestuous body of history and 'deals with events in terms of their most unique manifestations' (NGH, 154). As such, traditional historical events such as 'a decision, a treaty, a reign, or a battle' (NGH, 154) come to be perceived in terms of shifting relationships of force and power. The task of genealogy is to draw attention to 'the various systems of subjection' (NGH, 148) that constitute history as a violent and repeated palimpsestuous play of 
dominations and forces, 'substitutions, displacements, disguised conquests, and systematic reversals' (NGH, 152).

Foucault's palimpsestuous view of history and its writing has had a significant impact on contemporary postcolonial theory, in which the palimpsest is used to figure the interpretation of culture and of history crucial to that discourse's social and political, as well as literary critical, enterprise. The palimpsest - as both a literal agent of history that was appropriated by Western palaeographers from Eastern monasteries during the nineteenth century, and as metaphor - represents 'history' not as natural evolution or progress but as the history of colonial expansion, the violent erasure and superimposition of cultures, and defiant and subversive persistence. The palimpsest represents history as colonialism, the past as a series of oppressions and displacements, the struggle and vying for territory and existence. For example, in 'Can the Subaltern Speak?' (1988), Gayatri Chakravorty Spivak describes the disqualified knowledges to which archaeology and genealogy respond as 'the subtext of the palimpsestic narrative of imperialism'. ${ }^{24}$ In this essay, Spivak argues that the figuration of history as palimpsest, and the subsequent reading demanded by it, are important to postcolonial theory,

not to describe "the way things really were" or to privilege the narrative of history as imperialism as the best version of history...[but] rather, to offer an account of how an explanation and narrative of reality was established as the normative one. ${ }^{25}$

Moreover, in 'The Aztec Palimpsest: Toward a New Understanding of Aztlán, Cultural Identity and History' (1988-90), Daniel Cooper Alarcón hesitantly and provisionally sets out the significance of the palimpsest as a tool and a trope that enables a critique and an understanding of cultural identity and history, both specifically 
(in relation to Chicano identity and history) and generally. Importantly, Alarcón argues that

the palimpsest's structure of interlocking, competing narratives has the advantage of preventing the dominant voice from completely silencing the others, thus encouraging scholarship to recognize and consider diversity. ${ }^{26}$

Scholars must not only listen to the previously silent or suppressed voices in history but analyse how such voices are interwoven with, speak in and through, infect and affect supposedly 'dominant' and 'authoritative' historical narratives. Alarcón represents culture and history as involuted palimpsests in which colonised and colonising discourses are interwoven, each affecting, infecting and inhabiting the other. This figuration avoids the tendency in postcolonial theory to "position colonial/imperial subjectivity as having epistemological and ontological primacy' and to feature 'native or subaltern subjects' as 'secondary "subject-effects" allowed, according to the critic, greater or lesser degrees of oppositional power within the discourse of empire'. ${ }^{27}$ This is not only because the palimpsest features colonised and coloniser's discourses as interlocking, but also because it embodies the potential for future reinscriptions of the cultural and historical palimpsest, for shifts in the balances of power and force. ${ }^{28}$

\section{Feminism and Queer Theory: From the palimpsestic to the palimpsestuous}

The concept of the palimpsest inhabits contemporary theories of the self and temporality in deconstructive and psychoanalytic discourse, as well as current postcolonial understandings of history and culture. In addition to this, conflicting 
understandings of the palimpsest also interestingly determine the opposed textual understanding and reading approaches of twentieth century Anglo-American feminist criticism on the one hand, and late twentieth century and early twenty-first century queer reading on the other. Discussions of the palimpsest within feminist criticism invariably occur in relation to the writing of the twentieth century poet and novelist H.D. For H.D.'s prose works are complex textual structures that combine autobiography and fiction, as well as heterosexual and homosexual texts. In entitling the first of these Palimpsest (1926), H.D. provides a name for such complex textual structures, and enforces a parallel between reading her work and reading palimpsests. Just as Foucault's categories of archaeology and genealogy correspond to traditional palimpsest reading and a more radical palimpsestuous reading, the interpretative practices of traditional feminist criticism and of more radical queer reading also correspond to these two different reading methods.

The palimpsest reading practice of traditional feminist criticism is first given expression in Sandra M. Gilbert and Susan Gubar's study The Madwoman in the Attic:

The Woman Writer and the Nineteenth-Century Literary Imagination (1979). Summarising their argument about the 'odd' narrative strategies of nineteenth century female writers, Gilbert and Gubar argue that,

in short, like the twentieth-century American poet H.D., who declared her aesthetic strategy by entitling one of her novels Palimpsest, women from Jane Austen and Mary Shelley to Emily Brontë and Emily Dickinson produced literary works that are in some sense palimpsestic, works whose surface designs conceal or obscure deeper, less accessible (and less socially acceptable) levels of meaning. Thus these authors managed the difficult task of achieving true female authority by simultaneously conforming to and subverting patriarchal literary standards. ${ }^{29}$

Gilbert and Gubar understand the structure of the palimpsest in terms of suppression 
and oppression, of layering and superimposition. The task of feminist criticism is to uncover and bring to light the suppressed women's narratives concealed within these texts. Such a project risks, however, ignoring or disregarding the overlying text of these narratives, as well as the complex relationality of the different texts which constitute their fabric. It is for this reason that Toril Moi fears that Gilbert and Gubar 'end up at times in a dangerously reductionist position: under the manifest text, which is nothing but a 'surface design' which 'conceals or obscures deeper, less accessible...levels of meaning' (73), lies the real truth of the texts'.

The reductionist risks of Gilbert and Gubar's approach - characteristic of that of Anglo-American feminist criticism in general - can be avoided by moving from a palimpsestic to a palimpsestuous understanding of the palimpsest and the texts it represents. This understanding is articulated by Shari Benstock in Women of the Left Bank, Paris, 1900-1940 (1986), again with reference to the writing of H.D. Here Benstock argues that the palimpsest is an entwined and encoded structure, not a layered one:

An understanding of the palimpsest reveals that masculine and feminine myths, male and female "texts," are not separate from each other, but entwined and encoded in each other by the very fact that they are culturally produced. There is not a second text ("a hidden meaning") embedded in and enclosed by the parent figure and surviving like a nut inside the shell. The second text cannot be "lifted" from the parent text complete and whole to refute the premises of the primary text. Indeed, the notions of "primary" and "secondary," "parent text" and "subtext," "surface meanings" and "hidden meanings," do not describe the operations of the palimpsest. Female experience cannot be extracted from the male experience, cannot be separately examined...; it is both indivisible from male experience and different from it. Indeed, in patriarchal societies, the "difference" of female experience is only known through its "indivisibility" from male cultural inscription. $^{31}$ 
Benstock perceives that the palimpsest is not simply a layered structure which contains a hidden text to be revealed. Rather, it is a queer structure in which are intertwined multiple and varying inscriptions, in this instance, both male and female. Whereas the traditional understanding of the palimpsest corresponds to a reading approach that seeks only to uncover or reveal, this more complex understanding of the structure of the palimpsest requires a more radical queer palimpsestuous reading.

Palimpsestuous queer reading does not uncover 'hidden' or 'repressed' narratives, but traces in the fabric of literary and cultural palimpsests the interlocking narratives of 'masculinity' and 'femininity', 'heterosexuality' and 'homosexuality' that characterise gender and sexual identity, writing, and culture. As such, it provides a reading method that can adequately respond to texts as complex and interwoven as H.D.'s, without reducing them to a single narrative, be it one of autobiography or homosexuality. Moreover, although H.D.'s texts are as complexly palimpsestuous as was her own sexual identity, emphasising the palimpsest's significance as a textual figure circumvents this problematic autobiographical 'phallacy' of feminist criticism, for it is not the gender or orientation of the author which determines a queer reading, but the palimpsestuous queerness of texts themselves.

\section{Conclusion: Queering the Palimpsest}

In conclusion, I would like to draw attention to the consequences of this palimpsestuous coupling of queer and the palimpsest, a union that draws attention to both the queerness of the palimpsest and the palimpsestuousness of queer. Identifying the structural similarities between the palimpsest and queer reveals that these terms 
must remain open to reinscription if they are to remain viable critical currency, an openness precisely embodied in and by the palimpsest.

In Queer Theory: An Introduction (1996), Annamarie Jagose provides a brief history of the word 'queer' in order to explain and contextualise its most recent semantic manifestation in the context of late-twentieth century poststructuralist thought. She explains that "while the mobilisation of queer in its most recent sense cannot be dated exactly, it is generally understood to have been popularly adopted in the early 1990s'. ${ }^{32}$ She argues that poststructuralism's problematising of identity has led to criticism of the terms 'gay' and 'lesbian' as identity categories and opened the space for 'queer' as a model of difference not of identity. Jagose argues that 'queer theory's debunking of stable sexes, genders and sexualities develops out of a specifically lesbian and gay reworking' of the poststructuralist figuration of identity. ${ }^{33}$ Jagose thus places the emergence of queer at the most recent end of the modern history of the decentring of the Cartesian subject, a history populated by such figures as Louis Althusser, Sigmund Freud, Ferdinand de Saussure, Jacques Lacan and Michel Foucault. As I explore in my reading of De Quincey above, the palimpsest also takes a significant place in this history as a figure intimately related to the poststructuralist notion of the spectralised subject. 'Queer' and 'palimpsestuous' are therefore structurally comparable figures for the essential involutedness of identity, be it sexual, gender, or racial.

Moreover, queer and the palimpsest share a similar aetiology. The construction of queer as an intellectual model has been made possible by the insights of lesbian and gay studies; the construction of the concept of the palimpsest by De Quincey's essay and the subsequent figuration and refiguration of the palimpsest from 1845 to the present day. But both terms have been further realised in the context of what Jagose terms the 'historically specific knowledges which constitute late twentieth-century 
western thought'. ${ }^{34}$ Jagose demonstrates how this is the case in relation to 'queer'. In my introduction and elaboration of the notion of 'palimpsestuousness' in this essay, and in my engagements with the palimpsest in relation to deconstruction, psychoanalysis, postcolonial theory, feminism and queer theory, I aim to have examined and performed this reinscription in relation to the palimpsest.

In order for such concepts as palimpsestuousness and queer to remain critically effective, they must stay open to the possibility of further reinscription. Such is Judith Butler's argument in a critical assessment of the term queer at the end of Bodies that Matter: On the Discursive Limits of "Sex" (1993). Here Butler insists of queer that

if the term...is to be a site of collective contestation, the point of departure for a set of historical reflections and futural imaginings, it will have to remain that which is, in the present, never fully owned, but always and only redeployed, twisted, queered from a prior usage and in the direction of urgent and, expanding political purposes. ${ }^{35}$

Butler's insistence applies as equally to the concept of the palimpsest as it does to that of queer. For both concepts are governed

by the history of the usages that one never controlled, but that constrain the very usage that now emblematizes autonomy; by the future efforts to deploy the term against the grain of the current ones, and that will exceed the control of those who seek to set the course of the terms in the present. ${ }^{36}$

The concept of the palimpsest is not only determined by, but structurally embodies, this historicity of critical terms, and their perpetual openness to critical and imaginative reinscription - an openness that is necessary for the exposure, affirmation and reworking of that historicity, as well as for the present and future effectivity of such critical terms. 
The palimpsestuous coupling of queer and the palimpsest draws attention to both the queerness of the palimpsest and the palimpsestuousness of queer, not just as both these terms are applicable to descriptions of identity, but also as they can be extended to queer traditional understandings of history, identity, temporality, reading, writing and textuality. Identifying the queerness and queering power of palimpsestuousness points up its continuing capacity to reinscribe 'otherwise' traditional literary, critical, cultural and philosophical modes of thought.

In concluding 'The Dark Interpreter and the Palimpsest of Violence', Maniquis asserts that 'the palimpsest has suffered its own partial erasure and become only a remembered writing surface on which no more can be written'. ${ }^{37}$ This assertion is directly contradicted by Maniquis' essay, which adds another text to the history of the palimpsest even whilst denying that possibility. It is also contradicted by the weight of texts he cites, both past and present, in which the palimpsest is continually rewritten. Finally, his assertion is undermined by this essay which provides undeniable evidence of the past, present and continuing importance of the palimpsest in modern literary and cultural theory. In seeming recognition of this, Maniquis' final attempt to close down the palimpsest at the end of his essay is infected by unexpected expressions of uncertainty and possibility in relation to it, of expectations of the future event yet to come:

Surely it [the palimpsest] will settle into some succeeding taxonomy of mental forms awaiting elaboration in our decentred culture...But whatever new rhetorics of figuration we may need, we know that few narrative and textual figures have claimed more ideological power than the circular route between the conscious and the unconscious in images such as the palimpsest. If that particular figure has drifted into the past, it is only replaced by others in a cultural power of figuration that, of course, has not weakened - and never will. [emphases added] ${ }^{38}$ 
The palimpsest has not drifted into the past and never could. For in its persistent

figurative power and its theoretical adaptability it determines how we view the past and

the present, and embodies within itself the promise of the future.

\section{Notes}

${ }^{1}$ The Oxford English Dictionary's citation of De Quincey's essay as the first figurative use of the palimpsest is misleading here. Earlier figurative uses can be found in Plutarch and St. John Chrysostom. See Sir Edward Maunde Thompson, An Introduction to Greek and Latin Palaeography (Oxford: Clarendon Press, 1912), pp. 64-5 and Charles William Russell, 'Palimpsest Literature, And Its Editor, Cardinal Angelo Mai', in The Afternoon Lectures on Literature and Art (London: Bell and Daldy, 1867), p.100. Moreover, in the preface to 'The Wanderings of Cain' (1828), Samuel Taylor Coleridge declares that 'I have in vain tried to recover the lines from the palimpsest tablet of my memory.'

${ }^{2}$ Thomas De Quincey, 'The Palimpsest' in Thomas De Quincey: Confessions of An English Opium Eater And Other Writings, ed. Grevel Lindop (Oxford: Oxford University Press, 1998), p. 104. All subsequent references to De Quincey's writings are to this edition and are given in brackets in the text, preceded by TDQ.

${ }^{3}$ The term 'palimpsestuous' was coined as the French 'palimpsestueuse' by Philippe Lejeune in Moi Aussi (Paris: Éditions de Seuil, 1986), p. 115. It is used by Gérard Genette in Palimpsestes: La littérature au second degré (Paris: Editions de Seuil, 1982), p. 452, and is first used in English by Channa Newman and Claude Doubinsky when translating Genette in Gérard Genette, Palimpsests: Literature in the Second Degree, trans. Channa Newman and Claude Doubinsky (Lincoln and London: University of Nebraska Press, 1997), p. 399. The term has subsequently been employed in French by Jacques Derrida in Papier Machine: Le ruban de machine à écrire et autres réponses (Paris: Galilée, 2001), p. 46, and in English by Peggy Kamuf translating Derrida in 'Typewriter Ribbon: Limited Ink (2)' in Without Alibi, trans. Peggy Kamuf (Stanford: Stanford University Press, 2002), p. 83. It is also used by Nicholas Royle in The Uncanny (Manchester: Manchester University Press, 2003), p. 284. I wish to thank Nick for first drawing my attention to this term.

${ }_{4}^{4}$ Robert M. Maniquis, 'The Dark Interpreter and Palimpsest of Violence: De Quincey and the Unconscious' in Thomas De Quincey: Bicentenary Studies, ed. Robert Lance Snyder (Norman and London: University of Oklahoma Press, 1985), p. 133.

${ }^{5}$ Jacques Derrida, 'Border Lines', trans. James Hulbert in Deconstruction and Criticism, Harold Bloom, Paul de Man, Jacques Derrida, Geoffrey Hartman, J. Hillis Miller (New York: Continuum, 1999, orig. pub. 1979), p. 137.

${ }_{7}^{6}$ Maniquis, 'The Dark Interpreter', p. 134.

${ }^{7}$ I am indebted to Nick Levett for drawing my attention to this double reading. Earlier in 'Border Lines' Derrida in fact comments precisely on the untranslatability of the French 'pas': 'I have published a text that is untranslatable, starting with its title, "Pas," and published in "La double séance," referring to "dissemination in the refolding \{repli\} of the hymen": Pas de méthode \{"no method," but also "a methodological step" $\}$ for it: no path comes back in its circle to a first step, none proceeds from the simple to the complex, none leads from a beginning to an end', p. 96.

${ }^{8}$ Gerald Gillespie, 'Here Comes Everybody/Nobody: Self as Overly Edited Palimpsest', New Comparison, 9 (1990), 3-15: here, p. 4. In this essay Gillespie traces the break down of the notion of the unitary self in Hume, Schopenhauer and Stirner in order 'to provide a backdrop against which to appreciate the artistic cooptation of the notion of the dissolution of self in Modernism' (p. 7). Gillespie provides a brief and fragmentary account which is significant for drawing attention to the larger picture of the post-Kantian breakdown of the concept of unitary identity in a proliferation of writers other than those normally attributed with the fictionalisation of identity - Nietzsche, Bergson and Freud. His sketch is thought-provoking, but let down both by an uniformed dismissal of the place in such an account of twentieth century thought in this area, particularly that of Jacques Derrida and Michael Foucault, whose 
work is passed off as 'the epigonal reverberations of nihilistic deconstruction' (p. 7). And, considering his title, Gillespie's elision of De Quincey in this history seems strange.

9 Jacques Derrida, Specters of Marx: The State of the Debt, the Work of Mourning and the New International, trans. Peggy Kamuf (New York and London: Routledge, 1994), p. xix.

${ }^{10}$ Jacques Derrida, 'Living On', trans. James Hulbert in Deconstruction and Criticism, Harold Bloom, Paul De Man, Jacques Derrida, Geoffrey Hartman, J. Hillis Miller (New York: Continuum, 1999, orig. pub. 1979), p. 77.

${ }^{11}$ Nicolas Abraham and Maria Torok, 'Introjection - Incorporation Mourning or Melancholia' in Psychoanalysis in France, ed. Serge Lebovici and Daniel Wiidlöcher (New York: International Universities Press, 1980), p. 3. All subsequent page references to this essay are given in brackets in the text, preceded by I.

${ }^{12}$ Jacques Derrida, 'Fors: The Anglish Words of Nicolas Abraham and Maria Torok' foreword to Nicolas Abraham and Maria Torok, The Wolf Man's Magic Word: A Cryptonymy, trans. Nicholas Rand (Minneapolis: University of Minnesota Press, 1986), p. xxxvi. All subsequent page references to this essay are given in brackets in the text, preceded by F.

${ }^{13}$ Nicolas Abraham and Maria Torok, The Wolf Man's Magic Word: A Cryptonymy, trans. Nicholas Rand (Minneapolis: University of Minnesota Press, 1986), p. 80.

${ }^{14}$ See Josephine McDonagh's insight that the palimpsest 'feigns a sense of depth while always in fact functioning on the surface level', 'Writings on the Mind: The Importance of the Palimpsest in Nineteenth Century Thought', Prose Studies, 10:1 (1987), 207-24: here, p. 211.

${ }^{15}$ McDonagh, 'Writings on the Mind', p. 209.

${ }_{17}^{16}$ McDonagh, 'Writings on the Mind', p. 209.

${ }^{17}$ Freud uses the palimpsest to figure the superimposed structure of the meanings of dreams which he describes as 'one of the most delicate, though also one of the most interesting, problems of dreaminterpretation', The Interpretation of Dreams (1900), The Penguin Freud Library, Vol. 4 (London: Penguin, 1991), p. 312. For references to palimpsests in Freud see Dreams, n. 2, pp. 215-6 and Jokes and Their Relation to the Unconscious (1905), The Penguin Freud Library, Vol. 6 (London: Penguin, 1991), p. 128.

${ }^{18}$ Such is the argument of Robert J. C. Young in his ingenious and seductive essay 'Freud's secret: The Interpretation of Dreams was a Gothic novel' in Sigmund Freud's The Interpretation of Dreams: New Interdisciplinary Essays, ed. Laura Marcus (Manchester: Manchester University Press, 1999).

${ }^{19}$ In 'Reasons to Forget: Scientists count the ways we get it wrong' (2004), John McCrone explains that it is only recently that social psychology and basic neuroscience has begun to break down the persistent fantasy of the brain as perfect archive and the general belief that memories must be captured as fixed traces. Recent advances have revealed that 'brains are evolved not for retrospection and contemplation but for intention and anticipation - for looking forwards rather than backwards, outwards rather than inwards, for being selective rather than merely retentive', and that what we understand as 'recollection' is better understood as 'imaginative reconstruction', or, in fact, anticipatory images. See 'Reasons to Forget: Scientists count the ways we get it wrong', Times Literary Supplement, January 30, 2004, 3-4.

20 Jacques Derrida, 'Freud and the Scene of Writing' in Writing and Difference (London: Routledge, 1978), p. 227. Such is the insight of Derrida's reading of Freud in this text, a text in which he formulates his reservations about 'the presuppositions of modelling itself', Jacques Derrida, Archive Fever: A Freudian Impression (Chicago and London: The University of Chicago Press, 1996), p. 15.

${ }^{21}$ Michael Foucault, 'Nietzsche, Genealogy, History' in Language, Counter-Memory, Practice: Selected Essays and Interviews, trans. Donald F. Bouchard and Sherry Simon (Ithaca, NY: Cornell University Press, 1996; first pub. 1977), p. 139. Subsequent page references to this essay are given in brackets in the text, preceded by NGH.

${ }_{22}^{23}$ Russell, 'Palimpsest Literature', p. 110.

${ }^{23}$ Michael Foucault, Power/Knowledge: Selected Interviews and Other Writings 1972-1977, ed. Colin Gordon (Harlow: Longman, 1980), pp. 50-51. Subsequent page references to this text are given in brackets in the text, preceded by PK.

${ }^{24}$ Gayatri Chakravorty Spivak, 'Can the Subaltern Speak?' in Cary Nelson and Lawrence Grossberg, eds., Marxism and the Interpretation of Culture (Urbana and Chicago: University of Illinois Press, 1988), p. 281.

${ }^{25}$ Spivak, 'Can the Subaltern Speak?', p. 281.

${ }^{26}$ Daniel Cooper Alarcón, 'The Aztec Palimpsest: Toward a New Understanding of Aztlán, Cultural Identity and History', Aztlán, 19:2 (1988-90), 33-68: here, pp. 35-6. 
${ }^{27}$ Patrick Williams and Laura Chrisman, 'Colonial Discourse and Post-Colonial Theory: An Introduction' in Colonial Discourse and Post-Colonial Theory: A Reader, ed. Patrick Williams and Laura Chrisman (Hemel Hempstead: Harvester Wheatsheaf, 1993), p. 16.

${ }^{28}$ For instance, see The African Palimpsest: Indigenization of Language in the West African Europhone Novel (1991) in which Zabus Chantal uses the palimpsest to figure 'the ways in which the imported and imposed standard code has been overwritten by indigenous writers in the processes of "indigenization", Bill Ashcroft, 'Review of The African Palimpsest: Indigenization of Language in the West African Europhone Novel. By Chantal Zabus', Modern Language Review, 88:1 (1993), 191-3: here, p. 192.

${ }^{29}$ Sandra M. Gilbert and Susan Gubar, The Madwoman in the Attic: The Woman Writer and the Nineteenth-Century Literary Imagination, $2^{\text {nd }}$ ed. (New Haven and London: Yale University Press, 2000; first pub. 1979), p. 73.

30 Toril Moi, Sexual/Textual Politics: Feminist Literary Theory (London and New York: Routledge, 1985), pp. 61-2.

${ }^{31}$ Shari Benstock, Women of the Left Bank, Paris 1900-1940 (London: Virago, 1994; first pub. Austin: University of Texas Press, 1986), p. 350.

${ }^{32}$ Annamarie Jagose, Queer Theory: An Introduction (New York: New York University Press, 1996), p. 76.

${ }^{33}$ Jagose, Queer Theory, p. 3.

34 Jagose, Queer Theory, p. 77.

35 Judith Butler, Bodies that Matter: On the Discursive Limits of "Sex" (New York and London: Routledge, 1993), p. 228.

36 Butler, Bodies that Matter, p. 228.

${ }^{37}$ Maniquis, 'The Dark Interpreter', p. 134.

${ }^{38}$ Maniquis, 'The Dark Interpreter', p. 134. 